\title{
HIV/AIDS messaging in Germany and Nigeria: A corpus linguistics study ${ }^{1}$
}

\author{
Bassey E. Antia \\ Department of Linguistics, University of the Western Cape, Private Bag X17, Bellville 7535, South Africa \\ E-mail: bantia@uwc.ac.za \\ Oliver Razum \\ Department of Epidemiology \& International Public Health, School of Public Health, University of Bielefeld, \\ Universitätsstraße 25, 33615 Bielefeld, Germany \\ E-mail: oliver.razum@uni-bielefeld.de
}

\begin{abstract}
Modelling success in HIV messaging is notoriously difficult in part because of the diversity of disciplines interested in the subject (e.g. public health, psychology, communication, education, sociology, linguistics) and the claims made in each, often on the basis of different coming-to-know processes. For instance, although relevant research in public health and communication emphasizes audience responses to messages but sometimes slights detailed analyses of the texts of these messages, work in applied linguistics tends to engage with texts without, however, framing its claims in the context of theories of behaviour. This study makes a case for attention to both text and behaviour by showing how a corpus linguistics study of texts of HIV messaging can be accommodated within a behavioural framework. An analysis of a corpus of HIV messages from Germany and Nigeria carried out from the standpoint of predictions of a behavioural theory suggests that only two German messages and one Nigerian message (out of the eleven messages in each national corpus) had the mix of features (high threat, high efficacy) predicted by the theory to elicit message acceptance. In view of the implication that the observed nexus between messaging and society does not necessarily translate into better acceptance prospects as defined within the particular behavioural theory, this study may be seen as problematising certain claims in applied linguistics research on HIV, especially recommendations dealing with the need for messaging to reflect local (knowledge) perspectives.
\end{abstract}

Keywords: HIV/AIDS messaging, Nigeria, Germany, Computer-assisted text analysis, Expanded Parallel Process Model

\section{Introduction}

Modelling rationales for successful messaging in HIV is notoriously difficult. Mooney (2010:252) speaks of the elusiveness of what constitutes successful messaging. In part, at

\footnotetext{
${ }^{1}$ Comments by anonymous reviewers are gratefully acknowledged. Part of the study reported here was carried out in the course of the first author's stay at the School of Public Health, University of Bielefeld, Germany. Funding by the Alexander von Humboldt Foundation is gratefully acknowledged.
} 
least, the challenge might be explained by the diversity of disciplines interested in the subject (e.g. public health, psychology, communication, education, sociology, linguistics) and what counts as fact or acceptable evidence in each discipline. There is, in other words, a diversity of epistemologies or coming-to-know processes.

For instance, some public health and communication researchers (e.g. Tavoosi, Zaferani, Enzevaei, Tajik and Ahmadinezhad 2004; Lal, Vasan, Sankara Sarma and Thankappan 2000; Iliyasu, Abubakar, Kabir and Aliyu 2000; Witte, Cameron, Lapinski and Nzyuko 1998) conducting studies of HIV-related knowledge, attitude, behaviour and practices tend to privilege audience responses to educational interventions on HIV (which resonate well with research in the field of psychology), but in the process they fail to analyse the materiality of the actual messages on which audience knowledge and responses are purportedly based. One consequence is that recommendations for improving messages may sometimes be difficult to understand or implement when one refers to the materiality of the existing messages that are said to be in need of improvement. On the other hand, although researchers in applied linguistics (e.g. Leap 1991, Mutembei, Emmelin, Lugalla and Dahlgren 2002, Ogechi 2005) tend to privilege close textual or semiotic analysis and to acknowledge issues of social structure, power and ideology (which resonate well with those in the fields of sociology and education), they do not frequently refer to behavioural research in making claims about what text features enhance or impede message uptake. As a result, recommendations relating to the need for messaging to reflect the agency of target audiences and local knowledge as well as local ways of talking about HIV/AIDS may be perceived as insufficiently nuanced or inadequately contested from the standpoint of behavioural research.

In order to evolve more rounded models of success factors in message design and, as a result, possibly enhance the uptake of research across disciplinary frontiers, it is clearly desirable to combine, where feasible, the methodological and interpretive paradigms of different disciplinary orientations. Taking message content rather than form as our focus, we attempt to show in this study how a corpus linguistics analysis that foregrounds concern with socioepidemiological readings can be combined with behavioural approaches to the study of HIV messaging to inform message design.

In psychologically-inspired communication research, which we take as our point of departure, although some communication research exists that explicitly engages with message features in the context of AIDS (e.g. Perloff \& Ray 1991; Treise \& Weigold 2001, Beaudoin 2007), attention among communication scholars has largely been focused on audience response to the message, rather than on how several message features interact to predict or bring about response. For example, in a listing of the applications of one health communication model, only one of 14 entries was an analysis of the contents of messages; all the others were audience-based (Witte 1998). In effect, then, analysis of the "message stimulus" by researchers appears to be mediated largely through audience response.

From an applied linguistics perspective, there are compelling reasons why the analysis of message features using methods of corpus linguistics is justified both in its own right and as a complement to audience studies, and needs to attract more attention in public health, communication and behavioural research on HIV/AIDS. First, the analysis of text corpora is able to provide a granular structure of components of health messaging. In this respect, the need to identify components of variables such as severity and susceptibility in health 
communication models has been stressed (Rogers \& Prentice-Dunn 1997). Second, as a result of this, findings of corpus analytical studies have the potential of making message design a more conscious process, encouraging formative or in-process evaluation. Third, through attention to repetition or frequencies in text, such corpus-based studies easily allow for an objective identification of priorities or emphases in national public enlightenment initiatives. Fourth, because of the tractability, verifiability and quantitative nature of their findings, corpus analyses can facilitate message comparisons, cross-learning, as well as message optimisation or improvement. Fifth, corpus analyses potentially allow us to infer the context of social structure and organisation and, as a result, to explore the context in which message acceptance or rejection is expected to take place. In this way, message outcomes are framed in relation to societal structures, rather than (exclusively and naïvely) as the idiosyncratic disposition of individuals. Finally, corpus-based analyses are able to generate hypotheses for audience response research. Operating as it sometimes does with messages as holistic gestalts (e.g. "does this message make you feel susceptible to X?"), audience research can quite easily leave the analyst in the dark as to what specific message feature or set of features may have significantly triggered or failed to trigger particular feelings. Without this kind of insight, a recommendation by the researcher of message features for improving the communication becomes guesswork and lacks explicit empirical substantiation from the study on which it is purportedly based.

In this study, we employ the method of corpus linguistics to examine a collection of "small media" (posters, stickers, pamphlets, flyers, cards, etc.) messages on HIV/AIDS from Germany and Nigeria, in order to understand how messaging interacts with behaviour. The examination is done from the standpoint of the predictions of the Expanded Parallel Process Model, a health communication and psychology theory. The study seeks to:

a. identify the nature of the relationship between emphases in the messages and the socioeconomic and HIV profiles of Germany and Nigeria;

b. examine the distribution of threat and efficacy information (as these are understood in the theory to be used) within each country's HIV/AIDS messaging and comparatively across both national samples;

c. determine which national HIV/AIDS messaging sample has the most messages with the most theoretical likelihood of eliciting specific outcomes (acceptance, rejection) as these are understood in the analytical model adopted; and

d. indicate what one country can learn from the other in terms of message construction.

\section{Germany and Nigeria: socioeconomic and HIV/AIDS epidemiological profiles}

Germany and Nigeria were selected because they present different HIV/AIDS-related socioeconomic and epidemiological profiles, and they offer an interesting set of contrasting environmental factors which would necessarily influence messaging strategies. With approximately 67,000 persons living with HIV in Germany and close to 3.3 million in Nigeria (UNAIDS 2010), endemicity is lower in the former country and higher in the latter country. These prevalence figures may be partly explained by another indicator, namely, resources. Using data from the U.S. Central Intelligence Agency, the Indexmundi website reports that $70 \%$ of Nigeria's population lives below the poverty line compared to $15.5 \%$ in Germany (www.indexmundi.com). The Joint United Nations Programme on HIV/AIDS estimates that 
government expenditure on health is USD 2438 per capita in Germany versus USD 13 in Nigeria (UNAIDS 2006). Even though in Nigeria high infection rates among higher socioeconomic status individuals may sometimes contradict the relationship between poverty and HIV, the consensus is that, on a world scale, poverty is a reliable predictor of exposure to HIV (Basu 2004:156). Women in Nigeria, under extreme economic conditions, may even be forced into prostitution for existential reasons (UNAIDS 2010, Oruboloye, Caldwell and Caldwell 1994; Caldwell 1995); economic and/or cultural vulnerabilities often limit women's abilities to negotiate sex at home or in the work place (Smith 2007:1002). In contrast, the higher levels of economic empowerment in Germany suggest that lifestyle choices, rather than economically-motivated existential concerns, are the main risk factors for HIV. It has been estimated that at the end of 2005, approximately two-thirds of persons living with HIV in Germany were men who have sex with men (MSM), and that infection rates are rising among MSM in Germany as in several other European states (Marcus, Voss, Kollan and Hamouda 2006:157).

Besides prevalence and resources, a further relevant contrasting factor, with special significance for control efforts, has to do with cultural norms on the subject of sex talk. In Germany, it has been observed that people readily accept the public display of sex and the celebration of the erotic quality of the human body (Steve 2005). Discourse and practice related to the topic of sexuality are framed as an issue of freedom of expression as guaranteed by Article 5 of the German Constitution (Grundgesetz für die Bundesrepublik Deutschland 1949, amended 2012). This interpretation of sexuality, as freedom of expression, does not typically occur in Nigeria, a country which in the face of an increasing AIDS epidemic is still struggling with open talk about sex. In Nigeria sexuality is a very private matter (Esiet, Adebajo, Bello, Booth, Esiet, Esiet, Oyebola and Yusuf 2004:755).

The implications of these divergent contextual circumstances and cultural views on the conditions for message production and processing will be investigated more closely in the discussion section. For now, an overview of the theoretical model used for the analysis of the messages will be provided.

\section{Locating the relevant health-behaviour information in text: guidance from theory}

Witte's Extended Parallel Process Model (EPPM) has been used extensively in persuasive health communication research (Witte 1992 and 1998, Murray-Johnson \& Witte 2003, Green $\&$ Witte 2006). The claim made within this model is that there are four variables which determine whether a health message is accepted: perceived severity ("effects or dangers of X on me"), perceived susceptibility ("the likelihood of me contracting X"), perceived response efficacy of recommendation ("recommendation Y actually does avert or mitigate the effects of X"), and perceived self-efficacy ("I am able to do recommendation Y"). Severity and susceptibility together constitute threat, while response efficacy and self-efficacy constitute efficacy. Message acceptance in the model presupposes that the bases have been established for the emotional and cognitive processes that serve as proxies for a commitment to act in intended ways.

When the perception on these four variables is high, danger control processes are activated. Such activation is claimed to lead to message acceptance, and is equivalent to behaviourallyappropriate responses. However, the outcomes are different in the individual who either fails 
to perceive the threat, or whose evaluation leads to the conclusion that perceived threat outweighs available efficacy resources. In the former case, the outcome is one of null response to the message. In other words, message processing is aborted even before considerations of "can I?" or "does it really work?" begin. In the latter case where perception of threat is far greater than perception of efficacy, a process of fear control is initiated, which is parallel to that of danger control. Fear control engenders several kinds of attitudes: denial ("it can't happen to me"), defensive avoidance ("can we change the subject? It's too scary"), reactance ("you can't believe this, it is sheer manipulation") and heightened defiance (doing more of what the message says should not be done). The result of fear control is message rejection, which is qualitatively different from a null response.

The EPPM uses quantified perceptions of threat and efficacy (arrived at by mapping audience responses to a Likert-type scale) and various combinations of both variable types to make 12 predictions. These predictions are related to cognitive and emotional processes initiated during message processing, and the effect of these processes on message acceptance. On our reading, four of the propositions (1,2,4 and 5) deal directly with message outcomes, and can be operationalised meaningfully (as Prop 1', Prop 2', Prop 4' and Prop 5') for corpus analysis, as can be seen in Table 1.

Table 1. Operationalisation of select EPPM (cf. Witte 1998) predictions for corpus analysis

\begin{tabular}{|l|l|}
\hline Prop. 1 & $\begin{array}{l}\text { "When perceived threat is low, regardless of perceived efficacy } \\
\text { level, there will be no further processing of the message". }\end{array}$ \\
\hline Prop. 1' & $\begin{array}{l}\text { A message with low threat rate is more likely to be associated with } \\
\text { processing that terminates in a null response. }\end{array}$ \\
\hline Prop. 2 & $\begin{array}{l}\text { "As perceived threat increases when perceived efficacy is high, so } \\
\text { will message acceptance". }\end{array}$ \\
\hline Prop. 2' & $\begin{array}{l}\text { A message with high rates of both threat and efficacy is more likely } \\
\text { to be associated with processing that culminates in message } \\
\text { acceptance. }\end{array}$ \\
\hline Prop. 4 & $\begin{array}{l}\text { "As perceived threat increases when perceived efficacy is low, } \\
\text { people will do the opposite of what is advocated". }\end{array}$ \\
\hline Prop. 4' & $\begin{array}{l}\text { A message with high threat rate but low efficacy rate is more likely } \\
\text { to be associated with message rejection. }\end{array}$ \\
\hline Prop. 5 & $\begin{array}{l}\text { "As perceived threat increases when perceived efficacy is moderate, } \\
\text { message acceptance will first increase, and then decrease, resulting } \\
\text { in an inverted U-shaped function". }\end{array}$ \\
\hline Prop. 5' & $\begin{array}{l}\text { A message with moderate efficacy rate is more likely to be associated } \\
\text { with an initial message acceptance, but also with the risk of this } \\
\text { acceptance being eroded subsequently in the event of an upward } \\
\text { revision of threat estimates. }\end{array}$ \\
\hline
\end{tabular}

The EPPM is obviously similar to a number of other models upon which it draws. It is attractive not only because of the explicit formulation of its propositions, but because it offers an explanation as to why messages are accepted and why they sometimes produce negative outcomes. 


\section{Materials and methods}

While the EPPM provides the framework for interpreting the contents of the messages, the actual identification of the message contents is done from the perspective of corpus linguistics (Sinclair 1994, McEnery \& Wilson 1995; Teubert 2005). In its use in a range of fields, from language learning to cultural studies (McEnery \& Wilson 1995), corpus linguistics is concerned with drawing inferences from verifiable characteristics within texts. Not surprisingly, in light of Halliday's view of language functioning as "expression of and metaphor for social processes" (Halliday 1979:3), corpus linguists trust the text as a record of exploitable evidence (Sinclair 1994). A corpus is an electronic collection of texts assembled according to specific criteria.

As sources of messages for the analysis, the research made use of 11 comparable NigerianGerman message pairs. Parameters for pairing involved similarity of delivery medium (pamphlets, posters), target audience (youth, adventure seekers, etc.), and content thrust (e.g. testing for HIV). The appendix at the end of this paper presents a description of the 22 messages.

These public health educational materials were scanned for computer processing, using the suite of programs in the System Quirk Text Analysis software (which was developed at the University of Surrey's Department of Computing). For the software to be able to identify what aspects of the message samples correspond to each of the four EPPM variables and to quantify their occurrence, the following procedure was adopted: Firstly, each variable was decomposed into a number of themes as outlined in Table 2. For this purpose, eleven Nigerian pamphlets (excluding those under investigation) providing general information on HIV, and eleven German texts accessed from websites of AIDS organisations were used as a comparable corpus (that is, a collection of texts with similar characteristics such as subject matter, date, producer, consumer, purpose, etc.), and that serves to show that the collection under investigation has features that are typical or atypical of a given genre. Messages in each national comparable corpus were analysed to determine what thematic categories were employed in elaborating each of the variables (severity, susceptibility, response efficacy and self-efficacy). Every subsequent message served to confirm and/or add to categories derived from a preceding message analysis. The process was continued until no new categories could be identified.

Table 2. Decomposition of EPPM variables into constituent themes

\begin{tabular}{|l|l|}
\hline EPPM Variables & Themes for each variable \\
\hline Severity & $\begin{array}{l}\text { (1) discrimination, (2) other psychological challenges, (3) } \\
\text { pathological processes, (4) prognosis/challenges of } \\
\text { management }\end{array}$ \\
\hline Susceptibility & $\begin{array}{l}\text { (1) transmission, (2) predisposing lifestyles and diseases, (3) } \\
\text { quantifiers and spatial references (e.g. who is contracting HIV } \\
\text { where and in what numbers?) }\end{array}$ \\
\hline Response efficacy & $\begin{array}{l}\text { (1) sexual conduct (non-risk or lower risk behaviour), (2) } \\
\text { equipment use (non-risk or lower-risk conduct in use), (3) } \\
\text { circumspection vis-à-vis possibly contaminated material, (4) } \\
\text { treatment (management options: medicines, nutrition) and } \\
\text { benefits }\end{array}$ \\
\hline
\end{tabular}




\begin{tabular}{|l|l|}
\hline Self-efficacy & $\begin{array}{l}\text { (1) assurance (allaying fears regarding testing, seeking } \\
\text { treatment), (2) training (skills in implementing advocated } \\
\text { responses - condom use, abstinence, disinfection, etc.), (3) } \\
\text { addresses (ready availability of and access to sources of help), } \\
\text { (4) cost (reassurance that costs of accessing help are not } \\
\text { prohibitive) }\end{array}$ \\
\hline
\end{tabular}

In addition, for each theme and in each national corpus, a query lexicon was developed for use by the computer software. For instance, destroy would be a candidate query item for the theme "pathological processes" under the variable "severity"; composite search strings like $<$ AIDS $^{\wedge}$ cur $^{*}>,<$ AIDS $^{\wedge *}$ cur $^{*}>,<$ cur $^{* \wedge}$ AIDS $>,<$ cur $^{* \wedge}$ AIDS $>$ would enable the software to target propositional-type units of information that fall under "prognosis" which is a theme under "severity". Examples: <AIDS has no cure>, <AIDS cannot be cured $>$, <AIDS is incurable $>,<$ there is no cure for AIDS $>,<$ the incurability of AIDS ... $>$, and so on.

The actual analysis of the messages for attestations of EPPM variables involved running the two sets of messaging samples through a key-word-in-context (KWIC) program, using the constituted query lexicon. Besides presenting all the hits of a query string in a way that allows for human validation, a KWIC analysis also provides statistical information for each query string, which is important for quantification of message features.

After vetting the data from the software analysis (that is, removing false hits, duplicates, etc.), we determined the occurrence rate of threat and efficacy information in the messaging corpora as follows:

No. of occurrence x 1000 words

Total no. of words in national corpus

To obtain numerical specifications of high, moderate and low levels of both threat and efficacy in individual messages, we determined the occurrence of threat and efficacy in each message using the above formula. Then we established the median values for threat and efficacy information per country. In a given message, then, moderate threat or efficacy would be a value range that includes the median, while low and high are defined relative to a set of (per mille) points below and above the moderate range.

\section{Results}

The results are reported in the order in which the objectives of the study were stated.

\subsection{Emphases in messaging and country profiles}

While German messaging draws on the relative affluence of society as well as openness vis-àvis sex talk to communicate efficacy or empowerment, it refrains as much as possible from the use of threat, perhaps basing its non-alarmist stance on the relatively small numbers of seropositive individuals. On the other hand, Nigerian messaging frames efficacy around a set of values related to sexuality, while freely deploying threat. To illustrate, in terms of empowering sexual conduct (safer sex practices/objects), there are more diverse German than 
Nigerian hits in the automated search for a range of lower risk penetrative and non-penetrative sex acts and related objects: Kondome (condoms), Dental Dam (dental dam), Frischhaltefolie (plastic wrap as ersatz dental dam), Lecken (cunnilingus), Dildo (dildos), Sex toys (sex toys), Folterwerkzeug (paraphernalia for bondage-discipline, domination-submission, sadomasochism or BDSM), Fisting (fisting), Petting (caressing), Mastubieren/ Selbstbefriedigung (masturbation), Telefonsex (phone sex), Handschuhe (medical gloves as ersatz dental dam or for use during mutual masturbation), and so on.

With respect to training, messages in the German corpus were more likely than Nigerian messages to provide detailed directions for condom use. In contrast, the Nigerian repertoire on safe sex practices and objects hardly went beyond kissing and the rare but hesitant description of how to wear the male condom. Rather, empowering sexual conduct is framed in Nigerian messaging in terms of abstinence, faithfulness and delayed onset of sex. There are altogether 22 admonitions in this regard, whereas there is only one relevant hit in the German corpus (cf. text boxes 1 and 2. In these and all other text boxes containing computer-generated key words in context (KWIC) excerpts, the line references to the left of each text extract refer to a composite of message ID number - see the appendix - and the line in a given message from which the KWIC was generated. Thus, $8 \_96$ in the Nigerian corpus refers to line 96 in message ID 8).

Text box 1. Occurrences of abstinence-fidelity in the Nigerian corpus

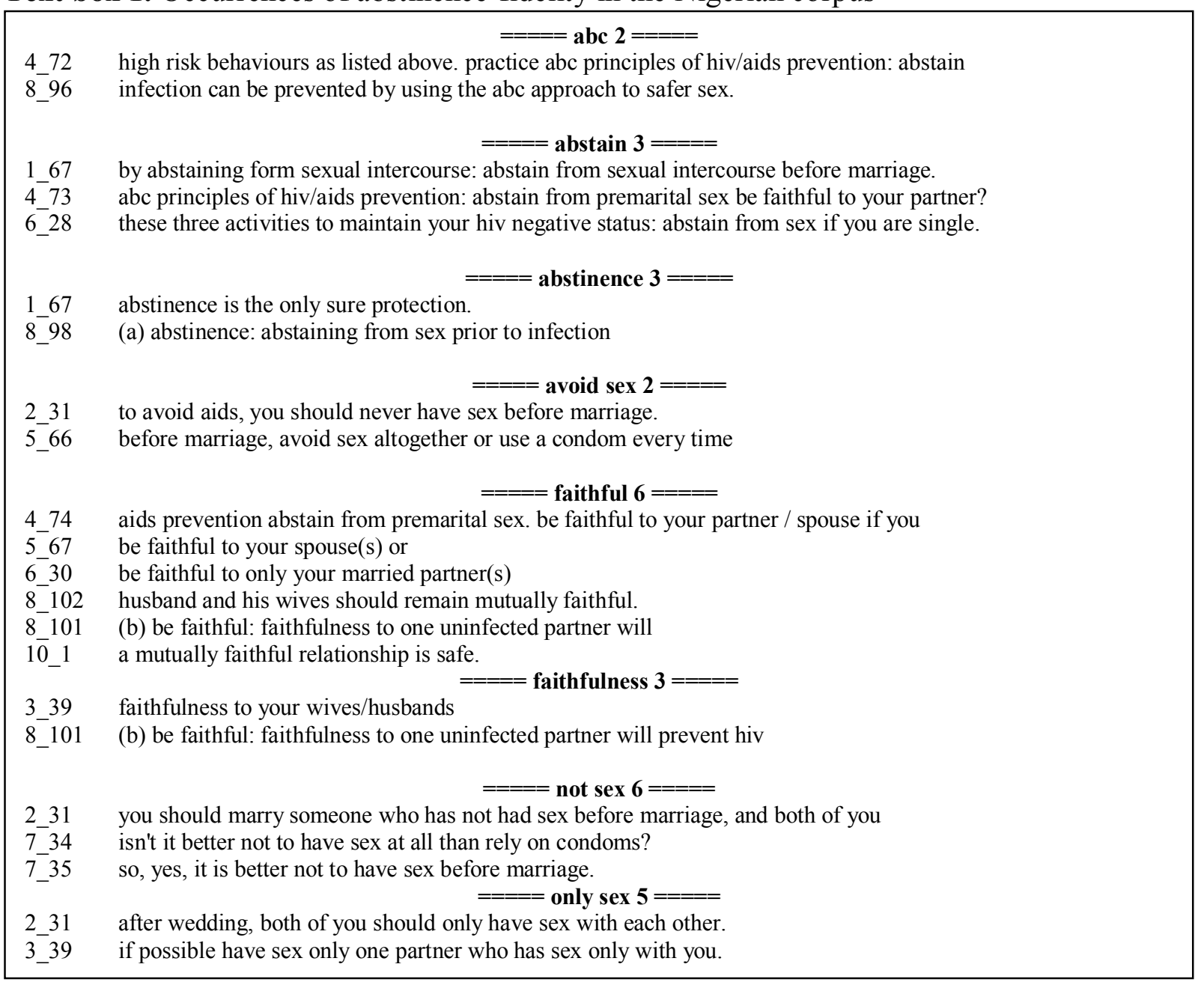


Text box 2. Faithfulness in the German corpus

\begin{tabular}{|ll|}
\hline $5 \_16$ & $\begin{array}{l}\text { krankheiten: möglichst früh erkennen und behandeln lassen. abc der häufigsten sexuell übertragbaren } \\
\text { krankheiten hiv/aids }\end{array}$ \\
& $====$ treu $2====$ \\
$1 \_39$ & $\begin{array}{l}\text { der stets für kurzweil sorgt und zugleich treu ist wie gold. } \\
\text { ich möchte treu sein, schaff es aber einfach nicht. } \\
====\text { treue } \mathbf{1}====\end{array}$ \\
$1 \_63$ & oder sie irgendwann entdecken, dass es mit der treue, die man sich geschworen hat, doch nicht \\
$1 \_18$ &
\end{tabular}

In text box 2, the hit for $\mathrm{ABC}$ is irrelevant to "Abstinence, Be faithful, use a Condom"; it refers rather to basics, and here the context is one of frequently transmitted sexual diseases. The first mention of treu (fidelity) in line 1_39 has a context that is equally irrelevant to HIV. The second occurrence and the third (in a different spelling variant treue) are relevant, but not as appeals; rather they occur in the context of contingency planning: what should happen when vows of fidelity cannot be kept.

Let us compare the manner in which quantifiers and spatial references are used (as indicators of susceptibility to HIV) in both messaging corpora. This will show, for example, how low seropositive numbers in Germany and the aversion in that country to threatening admonitions are reflected in the messages. See text boxes 3 and 4.

Text box 3. German use of quantifiers and spatial references

\begin{tabular}{|c|c|}
\hline & $=====$ deutschland $9=====$ \\
\hline 8299 & und lebenserwartung von menschen mit hiv in deutschland deutlich verbessert. \\
\hline $8 \_329$ & seit mitte der $80 \mathrm{er}$ jahre besteht in deutschland eine erfolgreiche und international beachtete arbeitsteilung zwis \\
\hline $8 \_318$ & die infektion häufig erst bei uns in deutschland festgestellt, wenn sich bereits erste symptome \\
\hline $8 \_311$ & in deutschland ist in dieser hinsicht manches schon erreicht \\
\hline & $\begin{array}{c}====\text { entwicklungsländern } 1===== \\
\text { (1) }\end{array}$ \\
\hline $8 \_318$ & hiv - infizierten aus osteuropa oder aus entwicklungsländern wird die infektion häufig erst bei uns \\
\hline & $====$ ländern $7====$ \\
\hline 8_204 & sahara gelegenen regionen afrikas, in einigen ländern asiens und in teilen süd - und \\
\hline 8_204 & auch in osteuropa und den ländern der ehemaligen sowjetunion hat sich die epidemie \\
\hline $8 \_222$ & die mitnahme eines kondomvorrats; in manchen ländern entsprechen die dort erhältlichen kondome nicht \\
\hline $8 \_260$ & \% gesenkt werden. ' 1 ländern, in denen hiv in der bevölkerung \\
\hline $8 \_284$ & - positiven - zumindest in den reicheren ländern, lange jahre mit dem virus \\
\hline & $====$ osteuropa $2====$ \\
\hline 8_204 & auch in osteuropa und den ländern der ehemaligen sowjetunion hat \\
\hline $8 \_318$ & bei hiv - infizierten aus osteuropa oder aus entwicklungsländern wird die infektion häufig \\
\hline 8_204 & $\begin{array}{l}\qquad====\text { welt } 1==== \\
\text { in anderen teilen der welt sind hiv und aids sehr viel stärker }\end{array}$ \\
\hline 8199 & $\begin{array}{l}====\text { weltregionen } 1=== \\
\text { migrant ( inn ) en aus weltregionen mit besonders starker hiv - verbreitung sowie }\end{array}$ \\
\hline
\end{tabular}

Text box 3 clearly shows the kind of self-adulation and self-assurance associated with the success of a control strategy whilst also displaying the more external nature of the threat. Line 8_299 suggests that the life expectancy of persons living with HIV/AIDS has risen in Germany; line 8_329 suggests that Germany has since the mid-80s had a successful and internationally acclaimed division of labour amongst agencies involved in AIDS control; line 
8 8 311 suggests that, in terms of HIV control, significant successes have been recorded in Germany; line 8_222 advises German travellers to take enough condoms along with them on trips abroad as condoms purchased at their destination may not be good quality; line 8_318 (and others) speaks of infected persons from Eastern Europe and developing countries; line 8_204 (and others) speaks of areas of the world with high HIV prevalence figures, etc.

While the German messaging uses these quantifying and spatial references to suggest calm at home and crisis overseas, the Nigerian corpus, as can be seen in text box 4 , uses these references to raise the threat of personal and collective susceptibility. Line 1_15 suggests the epidemic status of HIV; young people need to be cautious because half of the over 60 million who have been infected have been young people (1_56); daily, thousands of young people get infected (1_13); $5.8 \%$ of Nigerians are infected (1_56); the virus does not discriminate (1_33), and so on.

Text box 4. Nigerian use of quantifiers/spatial references

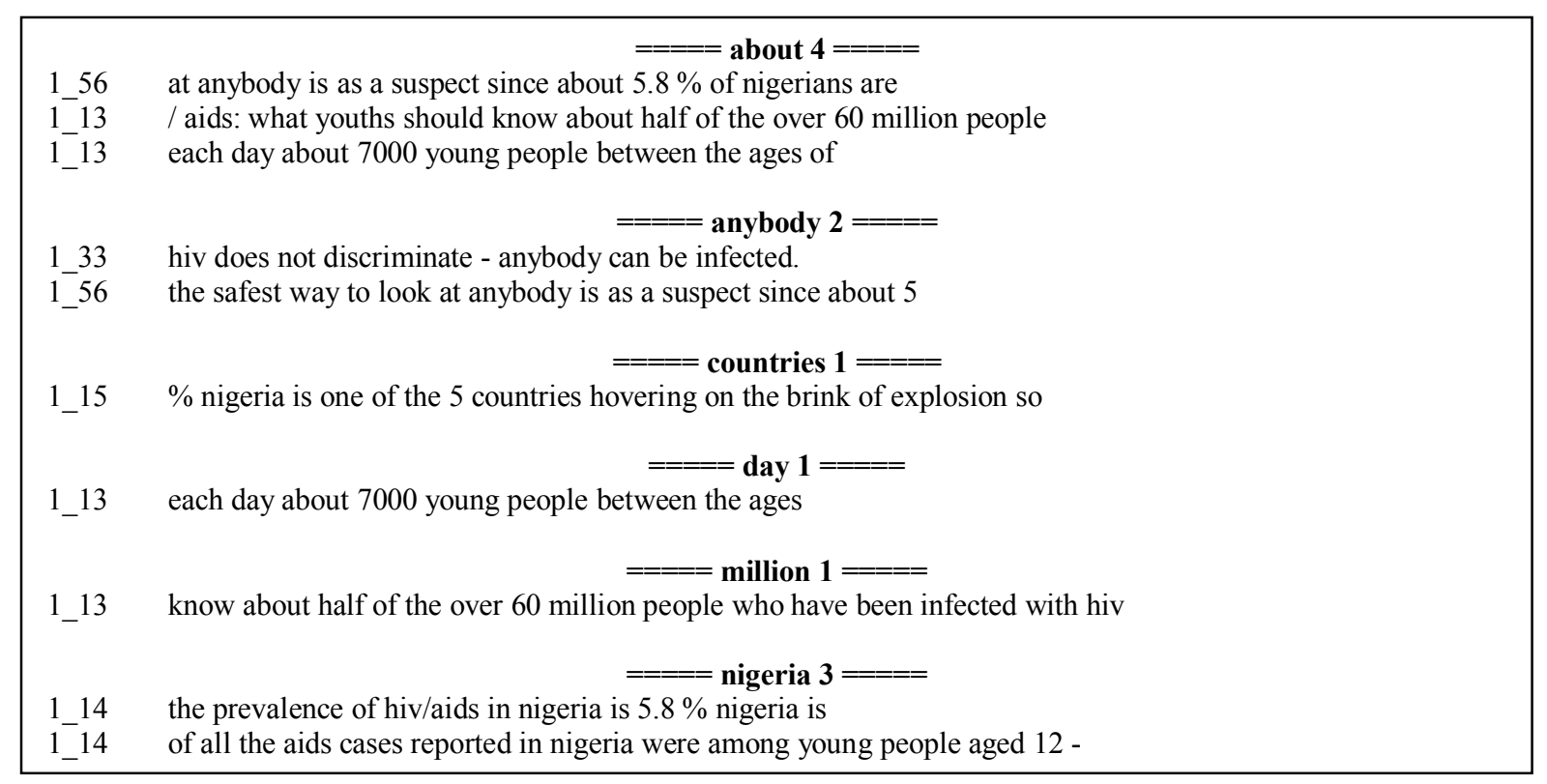

Subsequent sections will present findings from the specific standpoint of the EPPM, and should ultimately enable us to see how these messages, that are supportive of a default or nonactivist reading of the indicator set used, fare within the EPPM acceptance scheme.

\subsection{Distribution of EPPM variables within and across corpora}

The occurrence rate for each of the four EPPM variables per 1000 words of running text is presented in Table 3. 
Table 3. Occurrence rate of EPPM variables per 1000 words of text

\begin{tabular}{|l|c|c|}
\hline Variables & Nigeria & Germany \\
\hline Severity & 14.9 & 7.0 \\
\hline Susceptibility & 16.7 & 10.4 \\
\hline Threat total & 31.6 & 17.4 \\
\hline Response efficacy & 12.1 & 12.5 \\
\hline Self-efficacy & 8.9 & 21.1 \\
\hline Efficacy total & 21.1 & 33.6 \\
\hline
\end{tabular}

Table 3 shows that the Nigerian corpus consistently has higher word token rates for the threat variables than the German corpus. On the other hand, the German corpus consistently has higher rates for the efficacy variables. Nigeria's word rate for severity is more than twice the German figure, while the German rate for self-efficacy is almost three times the Nigerian number. The raw data from which the summary presented in Table 3 is derived shows, for instance, that for the theme of "pathological processes" under the variable 'severity', the Nigerian corpus had a 9.8\%o occurrence rate compared to Germany's 4.6\%o. This suggests that in Nigerian messaging the symptoms of HIV/AIDS are stressed more frequently per 1000 word tokens than in German messaging. On the other hand, the German corpus outperforms its Nigerian counterpart on all self-efficacy themes (of assurance, training, costs and addresses) by as much as a 2:1 ratio on three of the four themes.

To summarise, the overall picture that emerges is one in which the German corpus has higher frequencies in respect of potentially empowering items (assurance on confidentiality of testing and affordability of services, education on how to use condoms and addresses for obtaining help). The Nigerian corpus, on the other hand, has a higher frequency of fearevoking elements and elements of dissuasion with regards to sexual exposure.

\subsection{Message acceptance prospects}

The occurrence rate of EPPM variables per message as presented in Tables 4 and 5 is important for ultimately determining messages with the most theoretical likelihood of eliciting null response, acceptance, rejection and initial acceptance.

Table 4. Threat volume per thousand words per message

\begin{tabular}{|lccccccccccc|}
\hline Message & $\mathbf{1}$ & $\mathbf{2}$ & $\mathbf{3}$ & $\mathbf{4}$ & $\mathbf{5}$ & $\mathbf{6}$ & $\mathbf{7}$ & $\mathbf{8}$ & $\mathbf{9}$ & $\mathbf{1 0}$ & $\mathbf{1 1}$ \\
\hline Nigeria & 4.46 & 4.46 & 4.35 & 5.28 & 2.17 & 2.69 & 0 & 6.94 & 0.10 & 0.10 & 0.10 \\
\hline Germany & 1.23 & 1.23 & 1.89 & 1.11 & 3.06 & 1.45 & 0 & 6.52 & 0.00 & 0.00 & 0.11 \\
\hline
\end{tabular}

Table 5. Efficacy volume per thousand words per message

\begin{tabular}{|lccccccccccc|}
\hline Message & $\mathbf{1}$ & $\mathbf{2}$ & $\mathbf{3}$ & $\mathbf{4}$ & $\mathbf{5}$ & $\mathbf{6}$ & $\mathbf{7}$ & $\mathbf{8}$ & $\mathbf{9}$ & $\mathbf{1 0}$ & $\mathbf{1 1}$ \\
\hline Nigeria & 0.41 & 3.00 & 3.22 & 0.93 & 4.66 & 5.08 & 5.08 & 4.46 & 0.00 & 0.20 & 0.00 \\
\hline Germany & 2.23 & 2.62 & 2.73 & 1.78 & 7.42 & 4.41 & 1.72 & 9.20 & 0.05 & 0.16 & 0.11 \\
\hline
\end{tabular}

Based on an arranged order of rates for efficacy and threat in the eleven messages of each corpus, Table 6 presents the value range for moderate threat/efficacy in both corpora, in relation to which high and low threat/efficacy are defined. 
Table 6. Moderate value ranges for efficacy and threat

\begin{tabular}{|l|c|c|c|c|}
\hline & \multicolumn{2}{|c|}{ Nigeria } & \multicolumn{2}{c|}{ Germany } \\
\hline & $\begin{array}{c}\text { Threat } \\
\text { (median: 2.7) }\end{array}$ & $\begin{array}{c}\text { Efficacy } \\
\text { (median: 3) }\end{array}$ & $\begin{array}{c}\text { Threat } \\
\text { (median: 1.2) }\end{array}$ & $\begin{array}{c}\text { Efficacy } \\
\text { (median: 2.2) }\end{array}$ \\
\hline $\begin{array}{l}\text { Range for } \\
\text { moderate value }\end{array}$ & $2-2.99$ & $2-3.99$ & $1-1.99$ & $2-3.99$ \\
\hline
\end{tabular}

Defining higher and lower levels of threat/efficacy of message contents relative to the moderate values in Table 6 allows for the message categorisations in Table 7.

Table 7. Theoretical acceptance profiles of messages

\begin{tabular}{|l|c|c|}
\hline & $\begin{array}{l}\text { Nigerian } \\
\text { message ID }\end{array}$ & $\begin{array}{l}\text { German } \\
\text { message ID }\end{array}$ \\
\hline $\begin{array}{l}\text { 1. Which messages have low threat rate, this being associated } \\
\text { with processing that terminates in a null response? }\end{array}$ & $7,9,10,11$ & $7,9,10,11$ \\
\hline $\begin{array}{l}\text { 2. Which messages have high threat and high efficacy rates, this } \\
\text { configuration being associated with processing that terminates in } \\
\text { message acceptance? }\end{array}$ & 8 & 5,8 \\
\hline $\begin{array}{l}\text { 3. Which messages have high threat rate, but low efficacy rate, } \\
\text { this configuration being associated with message rejection? }\end{array}$ & 1,4 & None \\
\hline $\begin{array}{l}\text { 4. Which messages have moderate efficacy rate, these being } \\
\text { messages that are likely to elicit only initial acceptance? }\end{array}$ & 2,3 & $1,2,3$ \\
\hline 5. Unclassifiable, stricto sensu, in EPPM terms. ${ }^{2}$ & $\begin{array}{c}5,6 \\
\text { (moderate } \\
\text { threat, high } \\
\text { efficacy) }\end{array}$ & $\begin{array}{c}\text { (moderate } \\
\text { threat, high or } \\
\text { low efficacy) }\end{array}$ \\
\hline
\end{tabular}

Table 7 (serial number 2) makes it obvious that, from the standpoint of a corpus linguistics operationalisation of EPPM predictions, only one Nigerian and two German messages satisfy the requirements (high threat, high efficacy) for the activation of processes leading to fairly stable message acceptance. Two Nigerian and three German messages meet the criteria for initial acceptance, that is, acceptance that is not sustainable over time. As if to confirm the appropriateness of message pairing decisions made, four messages with identical message IDs on the Nigerian and German side are associated with prospects of a null response. Two Nigerian messages (but no German ones) are theoretically associated with rejection. How might the suboptimal messages have fared better according to EPPM?

\subsection{Cross-learning opportunities}

An obvious way of answering the research question concerning what each country can learn from this comparison of message strategies is to profile those messages with the most and the least acceptance prospects from the EPPM theoretical standpoint. Tables 8 and 9 show, respectively, what features were present in the relevant messages, and what features were lacking.

\footnotetext{
${ }^{2}$ However because EPPM is a fear appeal theory, its inherent logic might require that these otherwise unclassifiable messages be associated with a null response.
} 
Table 8. Profile of messages with high likelihood of acceptance

\begin{tabular}{|c|c|c|c|c|c|}
\hline & & & $\begin{array}{c}\text { Nigerian } \\
\text { message } 8\end{array}$ & $\begin{array}{c}\text { German } \\
\text { message } 5\end{array}$ & $\begin{array}{c}\text { German } \\
\text { message } 8\end{array}$ \\
\hline \multirow{7}{*}{ Threat } & \multirow{4}{*}{ Severity } & Discrimination & $\sqrt{ }$ & & $\sqrt{ }$ \\
\hline & & Psychological & & & $\sqrt{ }$ \\
\hline & & Pathological & & $\sqrt{ }$ & $\sqrt{ }$ \\
\hline & & Prognosis & & $\sqrt{ }$ & $\sqrt{ }$ \\
\hline & \multirow{3}{*}{ Susceptibility } & Transmission & $\sqrt{ }$ & $\sqrt{ }$ & $\sqrt{ }$ \\
\hline & & Predisposing & $\sqrt{ }$ & $\sqrt{ }$ & $\sqrt{ }$ \\
\hline & & Quantifiers/Spatial & $\sqrt{ }$ & & $\sqrt{ }$ \\
\hline \multirow{9}{*}{ Efficacy } & \multirow{5}{*}{$\begin{array}{c}\text { Response } \\
\text { efficacy }\end{array}$} & Testing & $\sqrt{ }$ & & $\sqrt{ }$ \\
\hline & & Sexual conduct & $\sqrt{ }$ & $\sqrt{ }$ & $\sqrt{ }$ \\
\hline & & Equipment use & $\sqrt{ }$ & $\sqrt{ }$ & $\sqrt{ }$ \\
\hline & & Circumspection & $\sqrt{ }$ & $\sqrt{ }$ & $\sqrt{ }$ \\
\hline & & Treatment & $\sqrt{ }$ & $\sqrt{ }$ & $\sqrt{ }$ \\
\hline & \multirow{4}{*}{ Self-efficacy } & Assurance & $\sqrt{ }$ & $\sqrt{ }$ & $\sqrt{ }$ \\
\hline & & Training & & $\sqrt{ }$ & $\sqrt{ }$ \\
\hline & & Costs & & $\sqrt{ }$ & $\sqrt{ }$ \\
\hline & & Addresses & $\sqrt{ }$ & $\sqrt{ }$ & $\sqrt{ }$ \\
\hline
\end{tabular}

Table 9. Profile of messages with low likelihood of acceptance

\begin{tabular}{|c|c|c|c|c|c|}
\hline & & & \multicolumn{2}{|c|}{ Null response } & Rejection \\
\hline & & & $\begin{array}{c}\text { Nigerian } \\
\text { message } 7\end{array}$ & $\begin{array}{c}\text { German } \\
\text { message } 7\end{array}$ & $\begin{array}{c}\text { Nigerian } \\
\text { message } 1\end{array}$ \\
\hline \multirow{7}{*}{ Threat } & \multirow{4}{*}{ Severity } & Discrimination & & & $\sqrt{ }$ \\
\hline & & Psychological & & & \\
\hline & & Pathological & & & $\sqrt{ }$ \\
\hline & & Prognosis & & & $\sqrt{ }$ \\
\hline & \multirow{3}{*}{ Susceptibility } & Transmission & & & $\sqrt{ }$ \\
\hline & & Predisposing & & & $\sqrt{ }$ \\
\hline & & Quantifiers/spatial & & $\sqrt{ }$ & $\sqrt{ }$ \\
\hline \multirow{9}{*}{ Efficacy } & \multirow{5}{*}{$\begin{array}{c}\text { Response } \\
\text { efficacy }\end{array}$} & Testing & & & \\
\hline & & Sex conduct & $\sqrt{ }$ & $\sqrt{ }$ & \\
\hline & & Equipment use & & & \\
\hline & & Circumspection & & & \\
\hline & & Treatment & & & \\
\hline & \multirow{4}{*}{ Self-efficacy } & Assurance & & & \\
\hline & & Training & $\sqrt{ }$ & $\sqrt{ }$ & \\
\hline & & Costs & $\sqrt{ }$ & & \\
\hline & & Addresses & $\sqrt{ }$ & $\sqrt{ }$ & \\
\hline
\end{tabular}

As inadequate as a mere attestation criterion is, it is clear that the more theoretically successful messages are those with features distributed over a wide range of possible parameters (Table 8). Even more interesting is the distribution of features in messages eliciting null response and rejection in Table 9. The null-response messages are condom- 
focused, and hardly contain explicit threat or health loss information. In the latter (rejection), which is associated only with a specific Nigerian message, there is no efficacy information.

\section{Discussion}

An attempt such as ours to relate text content analysis to behavioural theory was previously made by Beaudoin (2007), who draws similar conclusions on a number of points. In his study of HIV messages from 15 sub-Saharan African countries, Beaudoin uses six health psychology variables that are similar to our four (termed "frames") and notes the following: " $22.00 \%$ of the posters had zero frames, $14.40 \%$ had one frame, $31.40 \%$ had two frames, $17.40 \%$ had three frames, $12.30 \%$ had four frames, $21.10 \%$ had five frames and $0.40 \%$ had six frames" (Beaudoin 2007:202). He claims that attaining the goal of behaviour change is dependent on messages containing behavioural-change-relevant frames, and recommends that "potentially effective message frames should be infused in all HIV posters" (Beaudoin 2007:2044). This is quite consistent with the EPPM predictions as applied to our data.

Beaudoin (2007) also concludes that messaging content appears to be socially determined. He found a negative association between HIV rate in groups of countries and a benefit frame (comparable to our response efficacy) in the messaging from those countries. In other words, countries with high HIV rates tended to have messaging that did not contain frames dealing with response efficacy. Our use of a fear appeal theory enables us to discuss this common finding.

The data provided in our study, particularly in respect to the first and second research objectives, showed that the Nigerian corpus contained more threat-evoking elements than the German corpus. Conversely, the German corpus was seen to be more disinclined to threat, to contain more efficacy and empowerment related items, while at the same time playing down the internal challenge that HIV/AIDS represents. The discernible but questionable logic to the use of threat-evoking elements in our data finds confirmation elsewhere and invites discussion as to the value, appropriateness or ideological use of threat. Simply stated, the questionable logic seems to be as follows: raise the threat levels in messaging in resource-poor environments, which also happen to be areas of high endemicity; but lower the threat levels in resource-rich environments, which also tend to have lower levels of endemicity.

In reference to Uganda, which at a time had a high HIV-prevalence, several analysts have pointed to the role that threat played in communications which, alongside other factors like state commitment, led to a decline in new infection rates (Green \& Witte 2006, Stoneburner \& Low-Beer 2004). On this reading, then, the high threat volume in Nigerian messaging is quite consistent with what would be expected in a resource-poor environment that also has a high prevalence of HIV. This stance might be called "threat-driven behavioural interventionism". We will subsequently see suggestions of inappropriate and ideological uses of threat.

For now, though, it is noteworthy that Greene and Witte (2006:256-257) do not think that threat should be the guiding principle of messaging only in environments with high prevalence rates and weak resources. However, they do note the wall of opposition to the use of threat in environments of the north, specifically in the US. By extrapolation, then, it would seem that the comparatively less frequent use of threat in the German corpus could be a 
reflection of the non-crisis nature of HIV in Germany, or perhaps of another wall of opposition that has yet to come to terms with rising infection rates. The German disinclination towards fear appeals may also have been brought about by the success that is credited to this country's HIV/AIDS response strategy by its architects. The strategy of structural prevention, in part, posits that behaviours cannot be positively changed if the situations and conditions in which behaviours take place cannot be positively impacted. This means empowering people with a range of resources for them to be able to make desired adjustments without the need for pressure or repressive tactics (Deutsche AIDS-Hilfe 1998).

In view of the study's findings that only one Nigerian and two German messages meet the criteria for theoretical, stable acceptance, it is clear that the logic in the above triads - high threat in poverty and in high endemicity, but high efficacy in affluence and in low endemicity - describes a questionable strategy. It is in fact tempting to think in differently configured triads or to offer activist perspectives: high efficacy in poverty and in high endemicity, but high threat in affluence and in low endemicity. Indeed, it has been claimed that "high fear is only appropriate for the target audience members who can easily perform the recommended response (possess response efficacy), but do not recognize either the severity of the health threat or perceive that the threat will only impact others, not themselves" (Murray-Johnson \& Witte 2003:478). It can also be claimed that higher levels of efficacy (than are evident in the Nigerian corpus) should characterise messages intended for audiences that are well aware of the severity of the health threat, but are ordinarily powerless in averting, countering or mitigating the threat, or have reasons to feel this way. This is, in fact, one of what Beaudoin calls "bad practices" emerging from his study. He writes: "That HIV rate was negatively associated with benefits suggests that countries in which HIV is the greatest concern place the least emphasis on benefits" (Beaudoin 2007:204).

Given the absence of a critical mass of supportive structures for HIV control, messaging in Nigeria paints a picture of an ideological use of threat. Threat comes across as possibly serving to substitute for investments in infrastructure that politicians should be making. Another explanation, bordering on professional competence in message design, is also conceivable. Messaging clearly fails to draw attention to whatever resources are available (e.g. centres for voluntary counselling and testing, treatment, etc.). Perhaps, following up on the suggestion by Mooney (2010), we should also be offering a distrust of medical services as an explanation. Perhaps message designers believe that there is deep distrust of Western sexual and reproductive health technologies in their operating environments, as a result of which they choose to focus on "natural" methods such as abstinence and faithfulness. Such distrust has been reported in the context of initiatives to eradicate poliomyelitis (Renne 2006:1858).

On the German side, besides perhaps a generalised opposition to the use of threat, there is a sub-culture or industry that is emerging that precisely exploits this disinclination towards threat. While deploring the absence of an "AIDS is deadly" frame in German messaging and in the popular consciousness, a German national parliamentary debate broadcast on television (NTV, on $23^{\text {rd }}$ March 2007) also drew attention to social networking sites on the Internet that encourage adventurism in the form of seronegative individuals having unprotected sexual intercourse with seropositive individuals. Phenomena such as this, the ego trip or sense of security inherent in a portrayal of HIV as mainly an external threat, are perhaps the downsides of a mainly empowerment approach. 
Fundamentally, if the theoretical acceptance profiles of the analysed messages reflect actual audience responses, then behavioural change in the context of HIV/AIDS would have to challenge sociocultural givens and entrenched interests or ideologies that procure certain short-term personal or class benefits which, in the long run, may be inimical to control efforts.

Challenging entrenched interests and sociocultural norms is, undoubtedly, an arduous task. Also, on its own, messaging will not create the critical mass of institutional services for HIV testing and counselling, nor will it pay for blood screening equipment and other services. Yet, there are some presumably easier first steps. It is now acknowledged that in the developing world there tends to be an economic motivation for those practices that expose individuals to HIV infection (Basu 2004, Smith 2007, Mutonyi \& Kendrick 2010). As argued earlier, women in prostitution need a means of livelihood; men dislocated from their homes by the search for economic opportunity will have sexual urges that may not always be met within the marital institution. Following on from this, and given the need for greater self-efficacy empowerment in Nigeria, messaging in this country might point to options and opportunities for reducing the economic and other (e.g. work place) vulnerabilities that increase the risk of exposure to HIV. In other words, messages can draw attention to skills acquisition and entrepreneurial programmes and venture into such labour rights advocacy issues as the need for spousal/family reunions for migrant labourers. Talk of fidelity is likely to continue to founder without such contingencies. As sexual assault (Okonkwo \& Ibeh 2003) and unbridled materialism (Smith 2007, Caldwell 1995) increase exposure to HIV, messages might also draw attention to recourses available to individuals in the face of anticipated sexual violence and to the need for moderation in personal expenditures and tastes. In other words, producers of messages need to understand that messages also need to engage in advocacy for social change that is supportive of the behavioural change that they canvass.

The need for German messaging to scale up its threat level could also probably be met initially in more subtle ways that are less face-threatening. Clearly, with wide availability of highly active anti-retroviral therapy (HAART) options, symptomatology presumably loses some of its appeal as a source of fear-evoking elements. However, there still exist the personal adjustments, over and above the routine ones, which are an integral part of social life and which the seropositive individual has to make.

We see the implications of this study for applied linguistics research as residing in the framework it provides for contextualising and problematising claims that are sometimes made. For instance, when it is recommended that messages be couched in the preferred euphemisms, group-specific lexicalisations, and in the language hybrids of youths (cf. Ogechi 2005, Leap 1991), or that they should take into account local knowledge or cultural sensitivities (cf. Norton \& Higgins 2010), the goal is usually to ensure that messages are properly understood, easily relatable or talked about in a face-saving manner. Unfortunately, the achievement of these goals may not necessarily translate into behavioural change. There clearly is a need to link euphemisms and other group-specific forms of language use to models of health behaviour as well as to socioeconomic conditions and HIV-epidemiology. Such coupling potentially opens up a new vista of research opportunities. The question might, for example, be asked if there are specific behavioural variables (susceptibility, severity, response efficacy, self-efficacy) in respect of which certain forms of language use facilitate or impede behavioural change. 
In this connection, it seems that in the late 1980s and early 1990s, contracting HIV in Nigeria may have been fuelled by the trivial and euphemistic ways in which the admittedly new condition was referred to, especially by the youth. HIV was often seen as a condition belonging to the group of "gentleman's diseases" alongside gonorrhoea and syphilis. The contraction of gonorrhoea and syphilis signalled in some youth circles a kind of rite of passage to adulthood. It seems that the higher levels of granularity associated with relating behavioural variables to language features can enhance the uptake of applied linguistics research in other discourse communities.

A caveat to the results presented in this study and a comment on possible objections are in order at this point. The computer-assisted approach adopted in this study is unable support a multimodal analysis. In both national corpora, messages 9 to 11 were from the group of posters/postcards and stickers, contained substantial graphic material and performed poorly on the EPPM evaluation. But then, how would the fact that a picture is worth a thousand words have changed the results obtained on message outcomes? The assumption here, which has in fact been contested (cf. Banda \& Oketch 2011), is that pictures are readily processed in intended ways.

An examination of messages with graphics suggests that there would be no significant change. All the behaviourally-relevant graphics in the German corpus are efficacy-related, and would have had no effect on the German materials as there was no message in that corpus with relevant graphics whose classification could have been changed by more efficacy scores. In the Nigerian corpus, relevant graphics were threat-orientated and appeared in two materials: 1 and 3. The former already has high threat; although the latter has moderate threat, and might have been reclassified as high threat, such a reclassification would not be relevant in the EPPM prediction scheme as this particular message only has moderate efficacy. However, the foregoing does not deny the broader shortcoming of using word frequencies for analysis in a context where, in part because of concerns about literacy, imagery is a most potent means of communication.

In disputing these EPPM-driven evaluations, it might also be argued that health messaging is about creating a pool of complementary and interacting messages, with the consequence that the full complement of ideal message features need not be present in any one given message. True as this is, there is still no way of predicting which sort of preparatory message or set of messages an individual would encounter that would make the absence of an ideal feature configuration non-critical. The safer proposition (one suggested by our data and the adopted analytical framework) is that prospects of message acceptance are better when at least a component or an aspect of each of the four EPPM variables is reflected. However, this must not translate as information overload.

Finally, there are a number of issues related to the EPPM theory itself: the absence in this study of audience responses, and the study's implicit view of the infallibility of the EPPM. With respect to the latter, even though the EPPM has been shown to have explanatory adequacy in a range of contexts (noise-induced hearing loss in coal mines, library use, firearm injury, cervical cancer, HIV/AIDS), there clearly is a need for confirmatory studies using other theories. As for the former issue, but for logistic constraints, it certainly would have been desirable to determine if messages theoretically predicted to elicit acceptance would in fact be reported by respondents as the messages most likely to activate danger control 
processes. Audience response studies must be seen as important complements to textual analysis.

\section{Conclusion}

This study was motivated by the need to evolve more rounded models of what constitutes success in HIV messaging, given the multiplicity of disciplines interested in the subject matter. The study combined a corpus linguistics approach to text analysis with a behavioural theory to examine HIV messaging in Germany and Nigeria.

The study has shown that although Nigerian and German messages reflected the ideologies and practices of the societies in which they originated, they performed rather poorly on an analysis carried out within the framework of predictions of the Extended Parallel Process Model (EPPM). Only two German messages and one Nigerian message had the mix of features predicted by the EPPM to elicit message acceptance leading to danger control. The self-commending idea of including or reinforcing (e.g. repeating) certain message features requires measures that paradoxically challenge norms in the respective societies. The German messaging needs to underscore the threat that HIV represents to the individual, the family, and the economy, without of course fuelling stigmatisation. Nigerian messaging, on the other hand, needs to be more empowering, particularly in the area of self-efficacy.

\section{References}

Banda, F. and O. Oketch. 2011. Localizing HIV/AIDS discourse in a rural Kenyan community. Journal of Asian and African Studies 46(1): 19-37.

Basu, S. 2004. AIDS, empire and public health behaviorism. International Journal of Health Services 34(1): 155-164.

Beaudoin, C.E. 2007. HIV prevention in sub-Saharan Africa: A multilevel analysis of message frames and their social determinants. Health Promotion International 22(3): 198-206.

Caldwell, P. 1995. Prostitution and the risk of STDs and AIDS in Nigeria and Thailand. Health Transition Review, Supplement to Volume 5: 167-172.

Deutsche AIDS-Hilfe. 1998. Strukturelle Prävention. Ansichten zum Konzept der Deutschen AIDS-Hilfe. Berlin: Deutsche AIDS-Hilfe e.V.

Esiet, U.E., C.O. Adebajo, M.V. Bello, R. Booth, I.I. Esiet, N. Esiet, F. Oyebola and B. Yusuf. 2004. Nigeria. In R.T. Francouer and R.J. Noonan (eds.) The Continuum complete international encyclopedia of sexuality. New York: The Continuum International Publishing Group. pp. 752-780.

Fishbein, M. and I. Ajzen. 1981. Acceptance, yielding and impact: Cognitive processes in persuasion. In R.E. Petty, T.M. Ostrom and T.C. Brock (eds.) Cognitive responses in persuasion. Hillsdale, NJ: Erlbaum. pp. 339-360.

Green, E.C. and K. Witte. 2006. Can fear arousal in public health campaigns contribute to the decline of HIV prevalence? Journal of Health Communication 11: 245-259.

Grundgesetz für die Bundesrepublik Deutschland. 2012 [1949]. [Online] Available: http://www.gesetze-im-internet.de/bundesrecht/gg/gesamt.pdf [Accessed 15 September 2012].

Halliday, M. 1979. Language as social semiotic. The social interpretation of language and meaning. London: Edward Arnold. 
Higgins, C. and B. Norton. 2010. Introduction. Applied linguistics, local knowledge and HIV/AIDS. In C. Higgins and B. Norton (eds). Language and HIV/AIDS. Bristol: Multilingual Matters. pp. 1-19.

Iliyasu, Z., I.S. Abubakar, M. Kabir and M.H. Aliyu. 2006. Knowledge of HIV/AIDS and attitudes towards voluntary counselling and testing among adults. Journal of the National Medical Association 98(12): 1917-1922.

Indexmundi. n.d. Country comparison. Population below poverty line. [Online] Available: http://www.indexmundi.com/g/r.aspx?v=69 [Accessed 15 September 2012].

Lal, S.S., R.S. Vasan, P. Sankara Sarma and K.R. Thankappan. 2000. Knowledge and attitudes of college students in Kerala towards HIV/AIDS, sexually transmitted diseases and sexuality. The National Medical Journal of India 13(5): 231-236.

Leap, W.L. 1991. AIDS, linguistics and the study of non-neutral discourse. The Journal of Sex Research 28(2): 275-287.

Marcus, U., L. Voss, C. Kollan and O. Hamouda. 2006. HIV incidence increasing in MSM in Germany: Factors influencing infection dynamics. Euro Surveillance 11(9):157-160.

McEnery, T. and A. Wilson. 1996. Corpus linguistics. Edinburgh: Edinburgh University Press.

Mooney, A. 2010. Signs show the way: Reading HIV prevention on the Andaman Islands. In C. Higgins and B. Norton (eds.) Language and HIV/AIDS. Bristol: Multilingual Matters. pp. 252-270.

Murray-Johnson, L. and K. Witte. 2003. Looking toward the future: Health message design strategies. In T.L. Thompson, A.M. Dorsey, K.L. Miller and R. Parrot (eds.) Handbook of health communication. Marwah, NJ: Lawrence Erlbaum. pp. 473-496

Mutembei, A.K., M.A.C. Emmelin, J.L.P. Lugalla and L.G. Dahlgren. 2002. Communicating about AIDS-changes in understanding and coping with help of language in urban Kagera, Tanzania. Journal of Asian and African Studies 37(1): 1-16.

Mutonyi, H. and M. Kendrick. 2010. Ugandan students' representations of health literacies: a focus on HIV/AIDS. In C. Higgins \& B. Norton (eds.) Language and HIV/AIDS. Bristol: Multilingual Matters. pp. 38-62.

Ogechi, N.O. 2005. The language of sex and HIV/AIDS among university students in Kenya. Stichproben. Wiener Zeitschrift für kritische Afrikastudien 5(9): 123-149.

Okonkwo, J.E.N. and C.C. Ibeh. 2003. Female sexual assault in Nigeria. International Journal of Gynecology \& Obstetrics 83(3): 325-326.

Oruboloye, I.O., P. Caldwell and J.C. Caldwell. 1994. Commercial sex workers in Nigeria in the shadow of AIDS. In I.O. Oruboloye, J.C. Caldwell, P. Caldwell and G. Santow (eds.) Sexual networking and AIDS in Sub-Saharan Africa: behavioural research and the social context. Canberra: Australian National University, Health Transition Centre. pp. 101-116.

Perloff, R.M. and G.B. Ray. 1991. An analysis of AIDS brochures directed at intravenous drug users. Health Communication 3(2): 113-125.

Renne, E. 2006. Perspectives on polio and immunization in northern Nigeria. Social Science \& Medicine 63: 1857-1869.

Rogers, R.W. and S. Prentice-Dunn. 1997. Protection motivation theory. In D.S. Gochman (ed.) Handbook of health behavior research. Vol. 1. New York: Plenum Press.

Smith, D.J. 2007. Modern marriage, men's extramarital sex, and HIV risk in Southeastern Nigeria. American Journal of Public Health 97(6): 997-1005. 
Steves, R. 2005. Prudishness is one thing; censorship quite another. [Online] Available: http://www.usatoday.com/news/opinion/editorials/2005-08-24-censorship_x.htm [Accessed 20 July 2007].

Sinclair, J. 1994. Trust the text. In M. Coulthard (ed.). Advances in written text analysis. London \& New York: Routledge. pp. 12-25.

Stoneburner, R.L. and D. Low-Beer. 2004. Population-level HIV declines and behavioral risk avoidance in Uganda. Science 304: 714-718.

Tavoosi, A., A. Zaferani, A. Enzevaei, P. Tajik and Z. Ahmadinezhad. 2004. Knowledge and attitude towards HIV/AIDS among Iranian students. BMC Public Health 4(17).

[Online] Available: http://www.biomedcentral.com/1471-2458/4/17

Teubert, W. 2005. My version of corpus linguistics. International Journal of Corpus Linguistics 10(1): 1-13.

Treise, D. and M.F. Weigold. 2001. AIDS public service announcements: Effects of fear and repetition on predictors of condom use. Health Marketing Quarterly 18(3/4): 39-61.

UNAIDS. 2006. Report on the global AIDS epidemic 2006. [Online] Available: http://www.unaids.org/en/HIV_data/2006GlobalReport/default.asp [Accessed 19 July 2007].

UNAIDS. 2010. Report on the global AIDS epidemic 2010. [Online] Available: http://www.unaids.org/globalreport/documents/20101123_GlobalReport_full_en.pdf [Accessed 8 February 2012].

Witte, K. 1992. Putting the fear back into fear appeals: The Extended Parallel Process model. Communication Monographs 59: 329-349.

Witte, K. 1998. Fear as motivator, fear as inhibitor: Using the Extended Parallel Process Model to explain fear appeal successes and failures. In P.A. Andersen and L.K. Guerrero (eds.) The handbook of communication and emotion: Research, theory, applications, and contexts. San Diego, CA: Academic Press. pp. 242-251.

Witte, K., K.A. Cameron, M.K. Lapinski and S. Nzyuko. 1998. A theoretically based evaluation of HIV/AIDS prevention campaigns along the Trans-Africa Highway in Kenya. Journal of Health Communication 3: 345-363.

Appendix: Description of messages

\begin{tabular}{|c|c|c|c|c|c|}
\hline & Country & Title & Word count & Date & Source \\
\hline \multicolumn{6}{|c|}{ A. Pamphlet/brochure } \\
\hline \multirow[t]{2}{*}{1.} & Germany & $\begin{array}{l}\text { Erotische Streifzüge für } \\
\text { Liebeshungrige und } \\
\text { Sexperimentierfreudige. } \\
\text { ("Erotic excursions for } \\
\text { the love-hungry and } \\
\text { sexperimentalists") }\end{array}$ & 3260 & 2000 & $\begin{array}{l}\text { Deutsche Aids-Hilfe } \\
\text { Berlin }\end{array}$ \\
\hline & Nigeria & $\begin{array}{l}\text { That casual sex could } \\
\text { lead to AIDS. }\end{array}$ & 972 & $\begin{array}{l}\text { Not stated, } \\
\text { but in wide } \\
\text { circulation in } \\
2006\end{array}$ & $\begin{array}{l}\text { Pathfinder } \\
\text { international }\end{array}$ \\
\hline
\end{tabular}




\begin{tabular}{|c|c|c|c|c|c|}
\hline \multirow[t]{2}{*}{2.} & Germany & $\begin{array}{l}\text { Wir reden drüber. } \\
\text { ("Let's talk about it") }\end{array}$ & 771 & 2006 & $\begin{array}{l}\text { Deutsche Aids-Hilfe } \\
\text { (DAH) Berlin }\end{array}$ \\
\hline & Nigeria & AIDS \& You. & 1221 & 2001 & $\begin{array}{l}\text { ACTS. Fellowship of } \\
\text { Christian Students } \\
\text { (FCS) Aid for AIDS/ } \\
\text { Design for the Family } \\
\text { Project, National } \\
\text { Secretariat, Jos }\end{array}$ \\
\hline \multirow[t]{2}{*}{3.} & Germany & $\begin{array}{l}\text { HIV-Übertragung und } \\
\text { Aids-Gefahr. Wo Risken } \\
\text { bestehen und wo nicht. } \\
\text { ("HIV infection and } \\
\text { danger of AIDS: What is } \\
\text { risky and what is not") }\end{array}$ & 963 & 2006 & $\begin{array}{l}\text { Bundeszentrale für } \\
\text { gesundheitliche } \\
\text { Aufklärung (BZgA) } \\
\text { Cologne }\end{array}$ \\
\hline & Nigeria & $\begin{array}{l}\text { AIDS kills. Stop risky } \\
\text { behaviours. }\end{array}$ & 1133 & Not stated & $\begin{array}{l}\text { Adolescent Health \& } \\
\text { Information Project, } \\
\text { Kano }\end{array}$ \\
\hline \multirow[t]{2}{*}{4.} & Germany & $\begin{array}{l}\text { Was du schon immer } \\
\text { über Sex wissen } \\
\text { wolltest. ("What you } \\
\text { have always wanted to } \\
\text { know about sex") }\end{array}$ & 1270 & Not stated & $\begin{array}{l}\text { Wissenschaftliches } \\
\text { Institut der Ärtze } \\
\text { Deutschlands, Bonn \& } \\
\text { Bundeszentrale für } \\
\text { gesundheitliche } \\
\text { Aufklärung (BZgA) } \\
\text { Cologne }\end{array}$ \\
\hline & Nigeria & $\begin{array}{l}\text { What youths should } \\
\text { know. }\end{array}$ & 762 & 2005 & $\begin{array}{l}\text { A non-governmental } \\
\text { organisation called } \\
\text { GEARDI-HAF2, with } \\
\text { funding from } \\
\text { Nigeria's National } \\
\text { Action Committee for } \\
\text { AIDS }\end{array}$ \\
\hline \multirow[t]{2}{*}{5.} & Germany & $\begin{array}{l}\text { Schütz dich - auch beim } \\
\text { Sex. ("Protect yourself - } \\
\text { even during sex") }\end{array}$ & $\begin{array}{l}2885 \text { (only } \\
\text { HIV-related } \\
\text { segments) }\end{array}$ & 2006 & $\begin{array}{l}\text { Deutsche Aids-Hilfe } \\
\text { Berlin }\end{array}$ \\
\hline & Nigeria & $\begin{array}{l}\text { HIV/AIDS \& Sex. } \\
\text { Practical Advice. }\end{array}$ & 901 & Not stated & $\begin{array}{l}\text { Society for Family } \\
\text { Health, Abuja, with } \\
\text { support from USAID }\end{array}$ \\
\hline
\end{tabular}




\begin{tabular}{|c|c|c|c|c|c|}
\hline \multirow[t]{2}{*}{6.} & Germany & $\begin{array}{l}\text { Informationen rund um } \\
\text { den HIV-Test. ("All the } \\
\text { information about HIV } \\
\text { testing") }\end{array}$ & 2469 & 2005 & $\begin{array}{l}\text { Deutsche Aids-Hilfe } \\
\text { Berlin }\end{array}$ \\
\hline & Nigeria & $\begin{array}{l}\text { A new start for } \\
\text { everyone. All you need } \\
\text { to know about HIV } \\
\text { testing. }\end{array}$ & 1246 & $\begin{array}{l}\text { Not stated, } \\
\text { but in wide } \\
\text { circulation in } \\
2006\end{array}$ & $\begin{array}{l}\text { Society for Family } \\
\text { Health, Abuja, with } \\
\text { support from United } \\
\text { States AID Agency } \\
\text { (USAID) }\end{array}$ \\
\hline \multirow[t]{2}{*}{7.} & Germany & $\begin{array}{l}\text { Gib Gummi. Tipps zum } \\
\text { Kondomgebrauch. } \\
\text { ("Give "rubber". Tips on } \\
\text { condom use") }\end{array}$ & 510 & 2006 & $\begin{array}{l}\text { Deutsche Aids-Hilfe } \\
\text { Berlin }\end{array}$ \\
\hline & Nigeria & $\begin{array}{l}\text { Get the facts about } \\
\text { condoms. }\end{array}$ & 961 & $\begin{array}{l}\text { Not stated, } \\
\text { but in wide } \\
\text { circulation in } \\
2006\end{array}$ & $\begin{array}{l}\text { Society for Family } \\
\text { Health, Abuja }\end{array}$ \\
\hline \multirow[t]{2}{*}{8.} & Germany & $\begin{array}{l}\text { HIV. Heutiger } \\
\text { Wissenstand AIDS. } \\
\text { (HIV. State of } \\
\text { knowledge. AIDS) }\end{array}$ & 5684 & 2006 & $\begin{array}{l}\text { Deutsche Aids-Hilfe } \\
\text { Berlin }\end{array}$ \\
\hline & Nigeria & $\begin{array}{l}\text { HIV/AIDS. What to } \\
\text { know and do. }\end{array}$ & 2397 & $\begin{array}{l}\text { Not stated, } \\
\text { but in wide } \\
\text { circulation in } \\
2006\end{array}$ & $\begin{array}{l}\text { Family Health } \\
\text { International, with } \\
\text { USAID funding }\end{array}$ \\
\hline
\end{tabular}

B: Posters/Stickers/Postcards

\begin{tabular}{|l|l|l|l|l|l|}
\hline 9. & Germany & $\begin{array}{l}\text { Drücken? Es geht auch } \\
\text { anders. ("Injecting? There } \\
\text { are other ways") }\end{array}$ & 31 & $\begin{array}{c}\text { Not stated, } \\
\text { but part of } \\
\text { contemporary } \\
\text { corpus } \\
\text { supplied in } \\
2006 \text { by } \\
\text { Deutsche } \\
\text { AIDS-Hilfe, } \\
\text { Berlin. }\end{array}$ & $\begin{array}{l}\text { Deutsche Aids-Hilfe } \\
\text { Berlin }\end{array}$ \\
\cline { 3 - 6 } & Nigeria & Stay off drugs. & \multirow{2}{*}{$\begin{array}{c}\text { Not stated, } \\
\text { but in wide } \\
\text { circulation in } \\
2006\end{array}$} & Friends Network \\
& & & & \\
\hline
\end{tabular}




\begin{tabular}{|c|c|c|c|c|c|}
\hline \multirow[t]{2}{*}{10.} & Germany & $\begin{array}{l}\text { Gegen Kurzsichtigkeit! } \\
\text { ("Against short } \\
\text { sightedness") }\end{array}$ & 60 & 2007 & $\begin{array}{l}\text { Bundeszentrale für } \\
\text { gesundheitliche } \\
\text { Aufklärung }(\mathrm{BZgA}) \\
\text { Cologne }\end{array}$ \\
\hline & Nigeria & $\begin{array}{l}\text { AIDS. The killer disease } \\
\text { is here. }\end{array}$ & 18 & $\begin{array}{l}\text { Not stated, } \\
\text { but in wide } \\
\text { circulation in } \\
2006\end{array}$ & No indication. \\
\hline \multirow[t]{2}{*}{11.} & Germany & $\begin{array}{l}\text { Deine Firewall gegen } \\
\text { AIDS. } \\
\text { ("Your AIDS firewall") }\end{array}$ & 51 & $\begin{array}{c}\text { Not stated, } \\
\text { but part of } \\
\text { contemporary } \\
\text { corpus } \\
\text { supplied in } \\
2006 \text { by } \\
\text { Deutsche } \\
\text { AIDS-Hilfe, } \\
\text { Berlin. }\end{array}$ & $\begin{array}{l}\text { Deutsche Aids-Hilfe } \\
\text { Berlin }\end{array}$ \\
\hline & Nigeria & AIDS kills. & 8 & $\begin{array}{l}\text { Not stated, } \\
\text { but in wide } \\
\text { circulation in } \\
2006\end{array}$ & $\begin{array}{l}\text { University of } \\
\text { Maiduguri, with } \\
\text { funding from the U.S. } \\
\text { President's Emergency } \\
\text { Plans for AIDS Relief } \\
\text { (PEPFAR) for Africa } \\
\text { and the Caribbean } \\
\text { (PEPFAR) }\end{array}$ \\
\hline \multirow{2}{*}{$\begin{array}{l}\text { Total } \\
\text { word } \\
\text { count }\end{array}$} & Germany & \multicolumn{4}{|l|}{17,924} \\
\hline & Nigeria & \multicolumn{4}{|l|}{9,641} \\
\hline
\end{tabular}

